\title{
Effect of Plant Compost Enriched with Spirulina Platensis Algae as a Partial Replacement of Mineral N Fertilizers on Early Sweet Grapevine Masoud, A. A. B. \\ Pomology Department, Faculty of Agriculture, Assiut University, Egypt
}

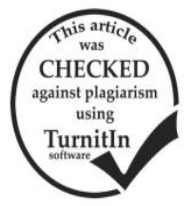

\section{ABSTRACT}

During 2014 and 2015 seasons, Early Sweet grapevines were fertilized with the recommended rate of N via $100 \%$ mineral $\mathrm{N}, 100 \%$ plant compost ( $\mathrm{p} \mathrm{c}$ ) enriched or not with Spirulina platensis algae(S p a) as well as via 25 to $75 \%$ inorganic N plus 25 to $75 \%$ plant compost with or without Spirulina platensis algae. The merit was replacing inorganic N partially by using plant compost enriched or not with Spirulina platensis algae. Growth characteristics, leaf pigments, N, P, and K, yield, quality of the berries and juice content of nitrite were investigated. Using N as 50\% inorganic N $+50 \%$ plant compost enriched with Spirulina platensis at $10 \mathrm{ml} /$ vine improved growth characteristics, yield, cluster weight and quality of the berries. There was a gradual effect on leaf pigments, N, P, K and fruit quality with reducing the percentages of inorganic $\mathrm{N}$ from 100 to $0.0 \%$ and increasing percentages of plant compost with or without the algae form 0.0 to $100 \%$. Juice content of nitrite and shot berries \% gradually declined with reducing inorganic $\mathrm{N}$ and increasing plant compost enriched or not with Spirulina platensis algae. Using plant compost enriched with Spirulina platensis was more favorable than using plant compost alone in this respect. A pronounced promotion on yield and fruit quality of Early Sweet cultivar was observed when the vines were subjected to the recommended rate of $\mathrm{N}$ as $50 \%$ inorganic N plus 50\% plant compost enriched with Spirulina platensis algae at $10 \mathrm{ml} / \mathrm{vine}$.

** Spirulina platensis algae (S p a) - plant compost ( p c)

Keywords: Inorganic N, plant compost, Spirulina platensis algae, Early Sweet grapevines, yield, berries quality.

\section{INTRODUCTION}

Poor yield of Early Sweet grapevines grown under Minia region conditions is considered a big problem facing grape growers. Many attempts were carried out for solving this problem by using organic fertilizers enriched with microorganisms such as Spirulina platensis algae ( $\mathrm{S} \mathrm{p}$ a). Adjusting $\mathrm{N}$ fertilization by using organic and biofertilization is useful for solving the previous problem for controlling growth and fruiting balance. $(S p$ a) has higher content in polyunsaturated fatty acids, pigments, amino acids such as leucine, isoleucine and valine, vitamins B12 and $\beta$-carotene, lipids, selenium, sugars, RNA, DNA, sulfated polysaccharides. Sulfoglycolipids, lipids and protein and pigments theallophcocianin (Beley, 2002 and 2008 and Henrikson, 2010). Application of the recommended rate of $\mathrm{N}$ through organic manures enriched with different microorganisms as a partial replacement of inorganic $\mathrm{N}$ was found by many workers to improve, growth and fruiting of grape cultivars (El-Rawy 2007; Mostafa 2008; EL-Kady2011;EL-Salhy et al 2011; Allam- Aida et al., 2012; Masoud 2012; Mahmoud, 2012; Abdelaal et al., 2013; AL-Khafagy 2013 ;ELSalhy et al 2013; Abd El- Kareem, 2014; Allam, 2014; Shaaban, 2014; Ali- Samar, 2015 ; El-Wany, 2015 and EL-Salhy et al 2017)

This study aimed to study the effect of using( $\mathrm{p} c)$ enriched with $(S p a)$ as a partial replacement of inorganic $\mathrm{N}$ fertilizer in Early Sweet grapevines grown under Minia conditions.

** Spirulina platensis algae (S p a) - plant compost (p c)

\section{MATERIALS AND METHODS}

This study was carried out during 2014 and 2015 seasons on fifty four uniform in vigour 10-year old Early sweet grapevines buded onto salt Greek grapevine rootstock grown in a private vineyard located at West Matay, Matay district, Minia Governorate where the soil is sandy well drained. The selected vines (54) were planted at $2 \times 3 \mathrm{~m}$ apart and pruned during the first week of Jan. during the two seasons using spur pruning system. The vines were trellised by Gable supporting system. Vine load was 57 eyes per vines on the basis of 15 fruiting spurs $x$ three eyes plus six replacement spurs $\mathrm{x}$ two eyes. Drip irrigation system was followed using well water containing $250 \mathrm{ppm}$ salinity. Soil analysis was done according to Peach and Tracey (1968).

Table 1. Soil's analysis :

\begin{tabular}{|c|c|c|c|}
\hline Characters & Values & Characters & Values \\
\hline \multicolumn{4}{|c|}{ Particle size distribution } \\
\hline Clay \% & 32.2 & $P$ & 3.3 \\
\hline Silt \% & 18.1 & $\mathrm{~K}$ & 80.0 \\
\hline Sand $\%$ & 49.0 & $\mathrm{Ca}$ & 71.0 \\
\hline Texture & Sandy & $\mathrm{Mg}$ & 5.0 \\
\hline $\begin{array}{l}\mathrm{pH} \\
(1: 2.5 \text { extract })\end{array}$ & 8.80 & \multicolumn{2}{|c|}{$\begin{array}{l}\text { EDTA extractable available } \\
\text { micronutrients (ppm) }\end{array}$} \\
\hline E.C. $\mathrm{mmhos} / 1 \mathrm{~cm} 25 \mathrm{oC}$ & 0.73 & $\mathrm{Zn}$ & 2.2 \\
\hline Organic matter \% & 1.2 & $\mathrm{Fe}$ & 1.7 \\
\hline Total CaCO3 \% & 20 & $\mathrm{MN}$ & 0.8 \\
\hline \multicolumn{2}{|c|}{ Available macronutrients (ppm) } & $\mathrm{Cu}$ & 0.8 \\
\hline $\mathrm{N}$ & 22.0 & & \\
\hline
\end{tabular}

All the (54) vines received all the horticultural practices that were already done in the vineyard except inorganic, organic and biofertilization treatments.

The following nine treatments application were included in this study

1- The recommended $\mathrm{N}(60 \mathrm{~N} / \mathrm{vine})$ via $100 \%$ inorganic N (179.0 g ammonium nitrate / vine / year) alone.

2- The recommended $\mathrm{N}$ via $75 \%$ inorganic $\mathrm{N}(134.25$ ammonium nitrate / vine/ year $)+25 \%(\mathrm{p} \mathrm{c})(2 \% \mathrm{~N})$ $(0.75 \mathrm{~kg} /$ vine / year $)$.

3- The recommended $\mathrm{N}$ via $75 \%$ inorganic $\mathrm{N}+25 \%$ $(\mathrm{p} \mathrm{c})+5 \mathrm{ml}(S p$ a) per vine.

4- The recommended $\mathrm{N}$ via $50 \%$ inorganic $\mathrm{N}(89.59$ ammonium nitrate / vine / year) $+50 \%$ (p c) $(1.5 \mathrm{~kg}$ / vine / year).

5- The recommended $\mathrm{N}$ via $50 \%$ inorganic $\mathrm{N}+50 \%$ (p c) $+10 \mathrm{ml}(\mathrm{Sp} a)$ per vine. 
6- The recommended $\mathrm{N}$ via $25 \%$ inorganic $\mathrm{N}$ (49.89 ammonium nitrate / vine/ year) $+75 \%$ (p c) $(2.25 \mathrm{~kg}$ / vine / year).

7- The recommended $\mathrm{N}$ via $25 \%$ inorganic $\mathrm{N}+75 \%$ plant compost $+15 \mathrm{ml}$ (S p a) per vine.

8- The recommended $\mathrm{N}$ via $0.0 \%$ inorganic $\mathrm{N}+100 \%$ (p c) $3.0 \mathrm{~kg} /$ vine / year).

9- The recommended $\mathrm{N}$ via $0.0 \%$ inorganic $\mathrm{N}+100 \%$ $(\mathrm{p} \mathrm{c})+20 \mathrm{ml}(S p a)$ per vine.

Treatments were replicated three times, two vines per each. Ammonium nitrate $(33.5 \% \mathrm{~N})$ as a source of inorganic $\mathrm{N}$ was divided into three unequal batches applied as $45 \%$ at growth start (1st week of Mar.), 35\% just after berry setting (mid. week of April and $20 \%$ one month after harvesting (last week of July). ( $\left.\begin{array}{ll}S p & a\end{array}\right)$ amount (5 to $20 \mathrm{ml}$ ) was mixed with plant compost (p c) before use. (p c) was added once at the last week of January. Randomized complete block design (RCBD) was followed.

Tables ( $2 \& 3)$ show the analysis of(p c)and(S p a).

Table 2. Analysis of the mature compost

\begin{tabular}{|c|c|c|c|c|c|}
\hline Parameter & Value & Parameter & Value & Parameter & Value \\
\hline Moisture \% & 29.0 & $\mathrm{C} / \mathrm{N}$ ratio & 18.82 & Total Mg \% & 1.21 \\
\hline Organic matter \% & 30.7 & Total $\mathrm{N} \%$ & 2.0 & Total Fe (ppm) & 320.0 \\
\hline Organic carbon $\%$ & 31.25 & Total P \% & 0.52 & Total Mn (ppm) & 45.0 \\
\hline $\mathrm{pH}$ & 8.5 & Total K \% & 1.12 & Total Zn (ppm) & 34.0 \\
\hline E/C. (ds. M-1) & 6.5 & Total $\mathrm{Ca} \%$ & 1.25 & Total $\mathrm{Cu}(\mathrm{ppm})$ & 42.0 \\
\hline
\end{tabular}

Table 3. Spirulina platensis analysis (Koru et al., 2008).

\begin{tabular}{lc}
\hline Parameters & Values \\
\hline & $(\mathrm{g} / 100 \mathrm{~g})$ \\
Moisture & 3.5 \\
Protein & 63.5 \\
Fat ( Lipids) & 9.5 \\
Fibre & 3.00 \\
Ash & 6.70 \\
N- free extract & 15 \\
\hline Colorants & \\
\hline Phycocyanin & $15.6 \mathrm{~g}$. \\
Carotenoids & $456.00 \mathrm{mg}$. \\
Chlorophyll- a & $1.30 \mathrm{~g}$. \\
\hline Vitamins & $(\mathrm{mg})$ \\
\hline Provitamin A & 213.00 \\
Thiamin $\left(\mathrm{V} . \mathrm{B}_{1}\right)$ & 1.92 \\
Riboflavin $\left(\mathrm{V} . \mathrm{B}_{2}\right)$ & 3.44 \\
Vitamin $\mathrm{B}_{6}$ & 0.49 \\
Vitamin $\mathrm{B}_{12}$ & 0.12 \\
Vitamin E & 10.40 \\
Niacin & 11.30 \\
Folic acid & 40 \\
Pantothenic acid & 0.94 \\
Inositol & 76.00 \\
\hline Minerals & \\
\hline Phosphorus & $916.00 \mathrm{mg}$. \\
Iron & $53.60 \mathrm{mg}$. \\
Calcium & $168 \mathrm{mg}$. \\
Potassium & $1.83 \mathrm{~g}$. \\
Sodium & $1.09 \mathrm{~g}$. \\
Magnesium & $250 \mathrm{mg}$. \\
\hline & \\
\hline
\end{tabular}

During the two seasons of study, were determine the following measurements:

1- Vegetative growth characteristics, the length of main shoot (cm.), leaves number / shoot and leaf area (cm2) (Ahmed and Morsy, 1999). The five basal internodes of ten canes per vine was used to calculate the average of can thickness $(\mathrm{cm})$ in just before winter pruning (first week of January by using a vernier caliper. Weight of pruning (in kg.) per vine was estimated by weighing the removal oneyear old wood after pruning (first week of January).

2-Leaf pigments namely a \& b total chlorophylls, and total carotenoids (mg/ 100 g F.W.) were estimated according to (Von- Wettstein, 1957 and Hiscoy and Isralston, 1979).

3- N, P, K \% in the petioles of the leaves according to (Peach and Tracey, 1968; Summer, 1985 and Wilde et al., 1985) on dry weight basis.

4- Yield (last week of June), clusters number / vine and cluster weight (g.)

5- Short berries $\%$, berry weight (g.), T.S.S. $\%$, reducing sugars $\%$, acidity $\%$ as tartaric acid $(\mathrm{g} / 100 \mathrm{ml})$ according to (Lane and Eynon, 1965 and A.O.A.C., 2000) and nitrite on the juice (ppm) (Sen and Donaldson, 1998 and Ridnour- Lisa et al., 2000).

New L.S.D. at 5\% test was used to make all comparison among treatment means (Snedecor and Cochran, 1967 and Mead et al., 1993).

\section{RESULTS AND DISCUSSION}

\section{1- Growth aspects:}

Table (4) cleared that fertilizing the vines with the recommended $\mathrm{N}$ via 50 to $75 \%$ inorganic $\mathrm{N}$ plus 25 to $50 \%$ (p c) enriched or not with $(S p a)$ at 5 to $10 \mathrm{ml} /$ vine significantly increased the length of main shoot, leaves number/ shoot, leaf area, cane thickness and pruning weight compared with using $\mathrm{N}$ as $100 \%$ inorganic $\mathrm{N}$ or when inorganic $\mathrm{N}$ was used at lower than $50 \%$. A significant reduction was observed on these growth aspects with using $\mathrm{N}$ as 0.0 to $25 \%$ inorganic $\mathrm{N}$ plus 75 to $100 \%$ (p c) with or without using $(S p a)$. Using ( $S p a$ ) with (p c)was significantly followed by enhancing all growth characteristics compared with using ( $\mathrm{p} \mathrm{c}$ ) alone. The vines that received $\mathrm{N}$ as $50 \%$ inorganic $\mathrm{N}+50 \%(\mathrm{p} \mathrm{c})$ enriched with $(S p$ a) at $10 \mathrm{ml} /$ vine had the highest values. On the other hand the vines received $\mathrm{N}$ completely via (p c) without $(S p$ a) had the minimum values. during both seasons of study. 
Table 4. Effect of using plant compost (p c) enriched with Spirulina platensis algae (S p a) on some growth aspects of Early sweet grapevines during 2014 and 2015 seasons.

\begin{tabular}{|c|c|c|c|c|c|c|c|c|c|c|}
\hline \multirow[t]{2}{*}{ Treatments } & \multicolumn{2}{|c|}{$\begin{array}{l}\text { Main shoot } \\
\text { length (cm.) }\end{array}$} & \multicolumn{2}{|c|}{$\begin{array}{c}\begin{array}{c}\text { No. of leaves / } \\
\text { shoot }\end{array} \\
\end{array}$} & \multicolumn{2}{|c|}{$\begin{array}{c}\text { Leaf area } \\
(\mathrm{cm})^{2}\end{array}$} & \multicolumn{2}{|c|}{$\begin{array}{c}\text { Pruning wood / } \\
\text { vine (kg.) }\end{array}$} & \multicolumn{2}{|c|}{$\begin{array}{c}\text { Cane } \\
\text { thickness }(\mathrm{cm})\end{array}$} \\
\hline & 2014 & 2015 & 2014 & 2015 & 2014 & 2015 & 2014 & 2015 & 2014 & 2015 \\
\hline $100 \%$ inorganic $\mathrm{N}$ & 95.2 & 96.8 & 20.0 & 22.0 & 141.0 & 142.3 & 1.71 & 1.80 & 1.21 & 1.17 \\
\hline $75 \%$ inorganic $+25 \%$ compost & 96.7 & 98.5 & 22.0 & 24.0 & 144.0 & 145.4 & 1.81 & 1.90 & 1.41 & 1.37 \\
\hline $75 \%$ inorganic $+25 \%$ compost $+S$ & 99.0 & 100.8 & 25.0 & 27.0 & 146.7 & 148.0 & 1.92 & 2.01 & 1.50 & 1.46 \\
\hline $50 \%$ inorganic $+50 \%$ compost & 102.0 & 103.9 & 27.0 & 29.0 & 149.0 & 150.3 & 2.00 & 2.09 & 1.60 & 1.56 \\
\hline $50 \%$ inorganic $+50 \%$ compost $+\mathrm{S}$ & 105.0 & 106.9 & 30.0 & 33.0 & 151.9 & 153.2 & 2.11 & 2.20 & 1.65 & 1.61 \\
\hline $25 \%$ inorganic $+25 \%$ compost & 92.0 & 93.9 & 16.0 & 18.0 & 136.0 & 137.4 & 1.52 & 1.60 & 1.10 & 1.04 \\
\hline $25 \%$ inorganic $+25 \%$ compost $+\mathrm{S}$ & 98.5 & 95.3 & 18.0 & 20.0 & 138.0 & 139.4 & 1.62 & 1.71 & 1.16 & 1.12 \\
\hline $0.0 \%$ inorganic $+100 \%$ compost & 87.7 & 89.6 & 12.0 & 14.0 & 131.0 & 132.7 & 1.31 & 1.40 & 0.99 & 0.94 \\
\hline $0.0 \%$ inorganic $+100 \%$ compost $+\mathrm{S}$ & 89.2 & 91.0 & 14.0 & 16.0 & 133.3 & 135.0 & 1.41 & 2.00 & 1.05 & 1.01 \\
\hline New L.S.D. at $5 \%$ & 1.4 & 1.2 & 2.0 & 2.0 & 1.2 & 1.2 & 0.07 & 0.07 & 0.05 & 0.05 \\
\hline
\end{tabular}

2-Leaf pigments and different nutrients:

Tables $(5 \&$ 6) showed that Early Sweet grapevines which treated with the recommended $\mathrm{N}$ via 0.0 to $75 \%$ inorganic $\mathrm{N}$ plus 25 to $100 \%$ (p c) with or without using $(S p$ a) at 5 to $20 \mathrm{ml} /$ vine significantly increased leaf pigments as well as $\mathrm{N}, \mathrm{P}$ and $\mathrm{K}$ nutrients in the leaves over the use of $\mathrm{N}$ as $100 \%$ inorganic $\mathrm{N}$. The increase in these chemical constituents was significantly correlated with reducing inorganic $\mathrm{N}$ from
100 to $0.0 \%$ and increasing percentages of (p c) enriched or not with $(S p a)$ at 5 to $20 \mathrm{ml} /$ vine. Using ( $S p$ a) along with ( $\mathrm{p} \mathrm{c}$ ) was superior to using ( $\mathrm{p} \mathrm{c}$ ) alone in enhancing these chemical constituents. The vines recived $\mathrm{N}$, as $100 \%$ inorganic $\mathrm{N}$ gave the lowest values. The vines with $\mathrm{N}$ through $100 \%$ (p c) enriched with $(S p$ a) at $20 \mathrm{ml} /$ vine (without using inorganic $\mathrm{N}$ ) gave the maximum values during the two seasons.

Table 5. Effect of using (p c) enriched with $(S p a)$ on leaf pigments and percentage of $N$ in the leaves of Early sweet grapevines during 2014 and 2015 seasons.

\begin{tabular}{|c|c|c|c|c|c|c|c|c|c|c|}
\hline \multirow[t]{2}{*}{ Treatments } & \multicolumn{2}{|c|}{$\begin{array}{c}\text { Chlorophyll a } \\
\text { (mg/ } 100 \text { g F.W.) }\end{array}$} & \multicolumn{2}{|c|}{$\begin{array}{c}\text { Chlorophyll b } \\
\text { (mg/ 100 g } \\
\text { F.W.) }\end{array}$} & \multicolumn{2}{|c|}{$\begin{array}{c}\text { Total } \\
\text { chlorophylls } \\
(\mathrm{mg} / 100 \mathrm{~g} \text { F.W. })\end{array}$} & \multicolumn{2}{|c|}{$\begin{array}{c}\text { Total } \\
\text { carotenoids } \\
(\mathrm{mg} / 100 \mathrm{~g} \\
\text { F.W. })\end{array}$} & \multicolumn{2}{|c|}{ Leaf $N \%$} \\
\hline & 2014 & 2015 & 2014 & 2015 & 2014 & 2015 & 2014 & 2015 & 2014 & 2015 \\
\hline $100 \%$ inorganic $\mathrm{N}$ & 4.3 & 4.5 & 2.3 & 2.1 & 6.6 & 6.6 & 2.1 & 1.9 & 1.51 & 1.49 \\
\hline $75 \%$ inorganic $+25 \%$ compost & 4.7 & 4.9 & 2.7 & 2.5 & 7.4 & 7.4 & 2.5 & 2.3 & 1.61 & 1.56 \\
\hline $75 \%$ inorganic $+25 \%$ compost $+S$ & 5.1 & 5.3 & 3.1 & 2.9 & 8.2 & 8.2 & 2.9 & 2.7 & 1.68 & 1.63 \\
\hline $50 \%$ inorganic $+50 \%$ compost & 5.5 & 5.7 & 3.4 & 3.2 & 8.9 & 8.9 & 3.2 & 3.0 & 1.75 & 1.70 \\
\hline $50 \%$ inorganic $+50 \%$ compost $+\mathrm{S}$ & 6.0 & 6.2 & 3.7 & 3.5 & 9.7 & 9.7 & 3.5 & 3.3 & 1.83 & 1.78 \\
\hline $25 \%$ inorganic $+25 \%$ compost & 6.3 & 6.7 & 4.0 & 3.8 & 10.3 & 10.5 & 3.8 & 3.6 & 1.90 & 1.86 \\
\hline $25 \%$ inorganic $+25 \%$ compost $+\mathrm{S}$ & 7.0 & 7.1 & 4.3 & 4.1 & 11.3 & 11.2 & 4.1 & 4.0 & 1.97 & 1.93 \\
\hline $0.0 \%$ inorganic $+100 \%$ compost & 7.4 & 7.6 & 4.6 & 4.4 & 12.0 & 12.0 & 4.4 & 4.3 & 2.05 & 1.99 \\
\hline $0.0 \%$ inorganic $+100 \%$ compost $+\mathrm{S}$ & 7.9 & 8.0 & 5.0 & 4.8 & 12.9 & 12.8 & 4.7 & 4.6 & 2.15 & 2.06 \\
\hline New L.S.D. at $5 \%$ & 0.3 & 0.3 & 0.3 & 0.3 & 0.4 & 0.4 & 0.3 & 0.3 & 0.05 & 0.05 \\
\hline
\end{tabular}

$\mathrm{S}=$ Spirulina platensis algae

Table 6. Effect of using( $\mathrm{p}$ c) enriched with $(S p a)$ on the percentages of $\mathrm{P}$ and $\mathrm{K}$ in the leaves, yield and cluster weight of Early sweet grapevines during 2014 and 2015 seasons.

\begin{tabular}{|c|c|c|c|c|c|c|c|c|c|c|}
\hline \multirow[t]{2}{*}{ Treatments } & \multicolumn{2}{|c|}{$\begin{array}{l}\text { Leaf } \\
\text { P \% }\end{array}$} & \multicolumn{2}{|c|}{$\begin{array}{l}\text { Leaf } \\
\text { K\% }\end{array}$} & \multicolumn{2}{|c|}{$\begin{array}{c}\text { No . of } \\
\text { clusters / vine }\end{array}$} & \multicolumn{2}{|c|}{$\begin{array}{c}\text { Cluster weight } \\
\text { (g.) }\end{array}$} & \multicolumn{2}{|c|}{$\begin{array}{c}\text { Yield / vine } \\
\text { (kg.) }\end{array}$} \\
\hline & 2014 & 2015 & 2014 & 2015 & 2014 & 2015 & 2014 & 2015 & 2014 & 2015 \\
\hline $100 \%$ inorganic $\mathrm{N}$ & 0.17 & 0.14 & 1.21 & 1.23 & 22.0 & 27.0 & 501.0 & 498.0 & 11.0 & 13.4 \\
\hline $75 \%$ inorganic $+25 \%$ compost & 0.21 & 0.17 & 0.27 & 0.30 & 22.0 & 29.0 & & & 11.3 & 14.8 \\
\hline $75 \%$ inorganic $+25 \%$ compost $+S$ & 0.24 & 0.21 & 0.35 & 0.37 & 22.0 & 31.0 & 526.0 & 523.0 & 11.6 & 16.2 \\
\hline $50 \%$ inorganic $+50 \%$ compost & 0.28 & 0.24 & 0.42 & 0.45 & 22.0 & 33.0 & 540.0 & & 11.9 & 17.7 \\
\hline $50 \%$ inorganic $+50 \%$ compost $+S$ & 0.31 & 0.27 & 0.50 & 0.53 & 22.0 & 35.0 & 553.0 & 0.0 & 12.2 & 19.3 \\
\hline $25 \%$ inorganic $+25 \%$ compost & 0.34 & 0.31 & 0.55 & 0.60 & 22.0 & 24.0 & 476.0 & & 10.5 & 11.4 \\
\hline $25 \%$ inorganic $+25 \%$ compost $+\mathrm{S}$ & 0.37 & 0.34 & 0.61 & 0.69 & 22.0 & 25.0 & 488.0 & & 10.7 & 12.1 \\
\hline $0.0 \%$ inorganic $+100 \%$ compost & 0.40 & 0.37 & 0.67 & 0.76 & 22.0 & 23.0 & 450.0 & 447.0 & 9.9 & 10.3 \\
\hline $0.0 \%$ inorganic $+100 \%$ compost $+\mathrm{S}$ & 0.43 & 0.41 & 0.74 & 0.85 & 22.0 & 24.0 & 463.0 & 460.0 & 10.2 & 11.6 \\
\hline New L.S.D. at $5 \%$ & 0.03 & 0.04 & 0.05 & 0.06 & NS & 2.0 & 12.0 & 12.0 & 0.03 & 0.4 \\
\hline
\end{tabular}

$\mathrm{S}=$ Spirulina platensis algae 
3- Yield and cluster weight:

Table (6) cleared that the application of the recommended rate $\mathrm{N}$ via 50 to $75 \%$ inorganic $\mathrm{N}$ plus 25 to $50 \%(\mathrm{p} \mathrm{c})$ enriched or not with $(\mathrm{S} \mathrm{p}$ a) significantly improved yield (kg.), clusters number per vine and cluster weight compared with using inorganic $\mathrm{N}$, when inorganic $\mathrm{N}$ was applied at $25 \%$ or when plant compost was added as $100 \%$. Using $\mathrm{N}$ as $100 \%$ inorganic $\mathrm{N}$ significantly increased compared to use $\mathrm{N}$ as $25 \%$ inorganic $\mathrm{N}$ as well as when $\mathrm{N}$ was added via (p c) at $100 \%$. Using inorganic $\mathrm{N}$ at lower than $50 \%$ significantly reduced the yield and cluster weight even with the application of (p c) enriched with $(S p a)$ at 10 $\mathrm{ml} /$ vine. Using ( $\mathrm{p} \mathrm{c}$ ) enriched with these algae was significantly superior to using ( $\mathrm{p} \mathrm{c}$ ) alone in improving the yield and cluster weight. Fertilizing with $\mathrm{N}$ as $50 \%$ inorganic $+50 \%$ (p c) enriched with $(S p$ a) gave the highest yield. The yield /vine was 12.2 and $19.3 \mathrm{~kg}$ compared with the yield of the vines that were fertilized with $\mathrm{N}$ inorganic form that reached 11.0 and $13.4 \mathrm{~kg}$, during the study seasons, respectively. The increament percentage in the yield reached 10.9 and $44.0 \%$ during 2014 and 2015 seasons, respectively.

\section{4- Percentages of shot berries:}

As shown in Table (7), fertilizing Early sweet grapevines with $\mathrm{N}$ as 0.0 to $75 \%$ inorganic $\mathrm{N}$ plus 25 to $100 \%$ (p c) enriched or not with ( $S p a$ ) significantly reduced the percentage of shot berries in the clusters compared with using $\mathrm{N}$ as $100 \%$ inorganic $\mathrm{N}$. The reduction percentage of shot berries was significantly related to the reduction in the percentage of inorganic $\mathrm{N}$ and the increase in the percentages of (p c) enriched or not with ( $\left.\begin{array}{ll}S p & a\end{array}\right)$. Using ( $\mathrm{p}$ c) enriched with $\left(\begin{array}{lll}S p & a\end{array}\right)$ caused a significant reduction in the percentages of shot berries compared with using ( $\mathrm{p} \mathrm{c}$ ) alone. $\mathrm{N}$ completely as inorganic $\mathrm{N}$ caused the highest values of shot berries $(12.0 \& 11.7 \%)$. While the vines fertilized with $\mathrm{N}$ completely via (p c) enriched with ( $\mathrm{S} \mathrm{p}$ a ) had the minimum values $(4.3 \% 3.6 \%)$ during the tow seasons.

\section{5-Quality of the berries:}

Ihe data in Table (7) showed that fertilization of the vines with $\mathrm{N}$ as 0.0 to $75 \%$ inorganic $\mathrm{N}$ plus 25 to $100 \%$ (p c) with or without the application of ( $S p a)$ was significantly improve the quality of the berries in favor of increasing berry weight, T.S.S. \%, and reducing sugars and decreasing total acidity $\%$ and nitrite in the juice compared to the use of $\mathrm{N}$ through $100 \%$ inorganic $\mathrm{N}$. The promotion on quality was significantly associated with reducing the percentages of inorganic $\mathrm{N}$ from 100 to $0.0 \%$ and at the same time increasing the percentages of ( $\mathrm{p} c)$ with or without $(S p a)$. The significant effect on quality of the berries due to using (p c) enriched with $(S p a)$ when compared with using plant compost alone. Supplying the vines with $\mathrm{N}$ as $100 \%$ (p c) enriched with ( $S p a)$ gave the best results during both seasons.

Table 7. Effect of using( $p$ c) enriched with $(S p a)$ on the percentage of shot berries and some physical and chemical characteristics of the berries of Early sweet grapevines during 2014 and 2015 seasons.

\begin{tabular}{|c|c|c|c|c|c|c|c|c|c|c|c|c|}
\hline \multirow[t]{2}{*}{ Treatments } & \multicolumn{2}{|c|}{$\begin{array}{c}\text { Shot berries } \\
\%\end{array}$} & \multicolumn{2}{|c|}{$\begin{array}{c}\text { Berry weight } \\
\text { (g.) }\end{array}$} & \multicolumn{2}{|c|}{$\begin{array}{c}\text { T.S.S. } \\
\%\end{array}$} & \multicolumn{2}{|c|}{$\begin{array}{l}\text { Reducing } \\
\text { sugars \% }\end{array}$} & \multicolumn{2}{|c|}{$\begin{array}{c}\text { Total acidity } \\
\%\end{array}$} & \multicolumn{2}{|c|}{$\begin{array}{c}\text { Nitrite juice } \\
\text { (ppm) }\end{array}$} \\
\hline & 2014 & 2015 & 2014 & 2015 & 2014 & 2015 & 2014 & 2015 & 2014 & 2015 & 2014 & 2015 \\
\hline $100 \%$ inorganic $\mathrm{N}$ & 12.0 & 11.7 & 5.00 & 5.02 & 18.0 & 17.9 & 13.9 & 13.8 & 0.719 & 0.718 & 1.92 & 1.99 \\
\hline $75 \%$ inorganic $+25 \%$ compost & 11.0 & 10.6 & 5.12 & 5.23 & 18.4 & 18.2 & 14.4 & 14.1 & 0.697 & 0.692 & 1.71 & 1.68 \\
\hline $75 \%$ inorganic $+25 \%$ compost $+S$ & 10.0 & 9.6 & 5.26 & 5.36 & 18.7 & 18.5 & 14.7 & 14.4 & 0.676 & 0.671 & 1.29 & 1.55 \\
\hline $50 \%$ inorganic $+50 \%$ compost & 8.8 & 8.6 & 5.55 & 5.50 & 19.0 & 18.9 & 15.0 & 14.8 & 0.650 & 0.650 & 1.51 & 1.45 \\
\hline $50 \%$ inorganic $+50 \%$ compost $+\mathrm{S}$ & 8.0 & 7.5 & 5.71 & 5.69 & 19.3 & 19.4 & 15.4 & 15.1 & 0.620 & 0.622 & 1.45 & 1.35 \\
\hline $25 \%$ inorganic $+25 \%$ compost & 7.0 & 6.6 & 5.92 & 5.93 & 19.6 & 19.8 & 15.8 & 15.5 & 0.592 & 0.600 & 1.30 & 1.25 \\
\hline $25 \%$ inorganic $+25 \%$ compost $+\mathrm{S}$ & 6.0 & 5.6 & 6.09 & 6.10 & 20.0 & 20.2 & 16.2 & 15.8 & 0.570 & 0.579 & 1.20 & 1.15 \\
\hline $0.0 \%$ inorganic $+0.0 \%$ compost & 5.0 & 4.6 & 6.22 & 6.23 & 20.4 & 20.5 & 16.5 & 16.1 & 0.550 & 0.550 & 1.10 & 1.04 \\
\hline $0.0 \%$ inorganic $+0.0 \%$ compost $+\mathrm{S}$ & 4.3 & 3.6 & 6.33 & 6.34 & 20.8 & 20.9 & 16.8 & 16.4 & 0.520 & 0.522 & 1.01 & 0.94 \\
\hline New L.S.D. at $5 \%$ & 0.9 & 1.0 & 0.11 & 0.12 & 0.3 & 0.3 & 0.3 & 0.3 & 0.020 & 0.22 & 0.11 & 0.12 \\
\hline
\end{tabular}

$\mathrm{S}=$ Spirulina platensis algae

\section{DISCUSSION}

Previous studies showed that organic and biofertilization especially with plant wastes enriched with microorganisms were favorable in reducing the expenses of mineral $\mathrm{N}$, salinity problems, antibiotics biosynthesis, (Kannaiyan, 2002, Irizar - Garza et al., 2003 and Mostafa 2008) (Miller et al., 1990).

The biochemical composition of Spirulina (showing that it rich, in the polyunsaturated fatty acid $\gamma$, high protein concentration, essential amino acids, high concentration of provitamin A, vitamin $\mathrm{B} 12$ and $\beta-$ carotene, essential fatty acids as linolenic acid, and polynsaturated fatty acids (Koru et al., 2008 Koru, 2009 and $\mathrm{Wu}$, et al., 2005). Cyanonacteria and algae had a wide range colored compounds, (Shekharam et al., 1987). $\mathrm{A}(S p a)$ contains about $13.5 \%$ carbohydrates. The Spirulina antiviral activity due to sulfated polysccharides, sulfoglycolipids, and a protein- bound pigment, theallophcocianin (Barron et al., 2008). Spirulina contains $2.2 \%-3.5 \%$ of RNA and $0.6 \%-1 \%$ of DNA, which represents less than $5 \%$ of these acids, based on dry weight. (Ciferri, 1983; Backer and Venkataraman, 1984, Belay 2002 and 2008; Diraman et al., 2009; Koru, 2009 and Henrikson, 2010).

The obtained results are in the same line with those reported by El-Rawy, (2007); Mostafa (2008); Masoud (2012); Abdelaal et al., (2013); El- Khafagy (2013); El-Salhy (2013); Abd El- Kareem (2014); Alam (2014); Shaaban (2014); Ali- Samar (2015); El- Wany (2015); and El-Salhy et al. (2017).

\section{CONCLUSION}

For solving the problem poor yield of Early sweet grapevines grown under Minia region conditions, it is 
advised to fertilize the vines with $\mathrm{N}(60 \mathrm{~g} /$ vine/ year) as $50 \%$ inorganic $\mathrm{N}+50 \%$ ( p c) enriched with $10 \mathrm{ml}(S p$ a).

\section{REFERENCES}

Abdelaal, A.H.M.; Ahmed, F.F.; Ebrahiem, M.E. and AbdelKareem, A.M.(2013): The beneficial effects of some humic acid, EM1 and weed control treatments on fruiting of Superior grapevines. Stem Cell.4(3): 25:32.

Abd El- Kareem, A.M. (2014): The beneficial effects of biofertilization and weed control on fruiting of Superior seedless grapevines. Ph. D. Thesis Fac. of Agric. El-Azhar Univ.Assiut. Egypt.

Ahmed, F. F. and Morsy, M. H. (1999): A new method for measuring leaf area in different fruit species. Minia J. of Agric. Res. \& Develop., Vol. (19) pp $97-105$.

Ali- Samar, S.H. (2015): Influence of reducing mineral nitrogen fertilizer partially by using plant compost enriched with Spirulina platensis algae on fruiting of Flame seedless grapevines. M. Sc. Thesis Fac. of Agric. Minia Univ. Egypt.

Allam- Aida, M.A.; Ahmed, F.F.; El- Hefnawy, N.N. ; El- Hewety, M.A. and El- Khafagy, H.A. (2012): Impact of inorganic $\mathrm{N}$ and compost enriched with some bacterial strains on fruiting of Superior and Flame seedless grapevines as well as nitrogenase activity in the soil. Minia J. of Agric. Res. \& Develop. (32): 3 pp. 115- 130.

Allam, H.M.M. (2014): Productive capacity of Superior grapevines in relation to application of some slow release fertilizers, effective microorganism and humic acid. Ph. D. Thesis Fac. of Agric. Minia Univ. Egypt.

AL-Khafagy, H.A.(2013): Physiological study on productivity and quality of some grape varieties under bio organic fertilization. $\mathrm{Ph}$. D. Thesis community serving and Environmental studies. Instit. Sadat city, Minufiya Univ.

A.O.A.C. (2000): Official Methods of analysis $17^{\text {th }}$ Ed., U.S.A. ISBN: 0- 935584-42-0.

Backer, E.W. and Venkataraman, L.V. (1984): Production and utilization of the blue- green algae Spirulina in India, Biomass, Volume 4, Issue 2, pp. 105-125.

Barron, L.B.; Torres- Valencia, M.K., ChamorroCevallos, G. and Zooiga-Estrada, A. (2008): Spirulina as an Antiviral Agent, in M.E. Gershwin \& Amha belay (ed.) Spirulina in human nutrition and health, CRC press, Taylor \& Francis, pp. 227.

Belay, A. (2002): The potential application of Spirulina (Arthrospira) as a nutritional and therapeutic supplement in health management, Journal of the American Nutraceutical Association, 5 (2):, pp. 124, Jama, 27.

Belay, A. (2008): Spirulina (Arthrospira) production and quality assurance in M.E. Gershwin and Amha Belay (ed.) Spirulina in human nutrition and health, CRC press, Taylor \& Francis , pp. 16-40.

Ciferri, O. (1983): Spirulina, the edible microorganism, Microbiological reviews, American Society for Microbiology. 47 (4): pp. 551-578.
Diraman, H.; Koru, E. and Dibekliolgu, H. (2009): Fatty acid profile of Spirulina platensis used as a food supplement. The Israli Journal of AquacultureBamideh 61(2): pp. 134-142.

El-Kady,A.M.(2011) : Effect of certain cultural treatments on growth and production of some seedless grape cultivars .Ph.D. Thesis ,Fac. Agric. Assiut. Univ. Egypt.

El-Rawy,H.A.(2007) Physiological studies on fertilization of King Ruby grapevines. Ph.D. Thesis, Fac. Agric. Assiut. Univ. Egypt.

El-Salhy,A.M, Abdel-Galil,H.A.,Ibrahim, R.A,Halim, A.Y and Sayed, M.K.(2017).Effect of yeast and bio-power on growth and fruiting of flame seedless grapevines Assiut. J. Agric. Sci.48(1-1) 191-201.

El-Salhy,A.M, K.I.Amen, A.AB.Masoud and A.A.EmanAbozeed(2011). Response of Rupy seedless and Red Roomy grapevines to application of some bio-fertilizers Assiut. J. Agric. Sci.,41(5):125-142.

El-Salhy,A.M, K.I.Amen,E.A.Hassan and S.H.Gaber (2013). The effects of different sources of nitrogen and potassium fertilizers on growth and fruiting of Thompson seedless grapevines. $1^{\text {st }}$ Assiut. Inter. Conf.Hort,24-25 February,p-116132.

El- Wany, A.R.M. (2015): Response of Thompson seedless grapevines to application of EM and fulvic acid as a partial replacement of organic $\mathrm{N}$ fertilizer. M. Sc. Thesis Fac. of Agric. Minia Univ. Egypt.

Henrikson, R. (2010): Spirulina World food, How this micro algae can transform your health and our planet, published by Ronore Enterprises, Inc. Po. Box gog. Hana, Maui, Hawaii 967i8 USA, ISBN 1453766987, pp. 195.

Hiscox,A. and Isralstan,B. (1979):A method for the extraction of chlorophyll from leaf tissue without maceratio.Cam.J.Bot. 57: 1332-1334.

Irizar-Garza, M.B. Vargas Vazquez, P.; Gaza Gareia, D.; Tuty Couoh, C.; Rojas Martineg, I.; Trujillo compus, A.; Garcia R.; Aguirre V Monteya, D.; Martineg Gonzaleg, J.C.; Aluarado Mendoza, S., Grageda Cabrea, D.; Valero Gazaa , J.; Aguirre Medina, J.F. (2003): Use of biofertilizes in Agricultural crops in the central region of Mexico. Agric. Tee. En Mexico, Instit. National de Investigations Mexico, 29 (2): 213 - 225.

Kannaiyan, S. (2002): Biotechnology of Biofertilizers. Alpha Sci. Inter. Ltd B.P. Bpx 4067 Pang borne R. 68 U.K. pp. 1-275.

Koru, E. (2009): Spirulina micro algae production and breeding in commercial. Turkey Journal of Agriculture, May June 2008, Issue: 11, year 3, pp. 133- 134.

Koru, E.; Cirik, S. and Turan, G. (2008): The use of Spirulina for feed production in Turkey University- industry co- operation project (USIGEM) project investigator and consultant Eids Koru, pp. 100, Bornova- Izmir/Turkey. 
Mead, R.; Currnow, R. N. and Harted, A. M. (1993): Statistical Methods in Agricultural and Experimental Biology. $2^{\text {nd }}$ Ed. Chapman and Hall, London pp. 54-60.

Miller, E. W.; Donahue, R. L. and Miller, J. U. (1990): Soils "An Introduction to soils and Plant Growth." $5^{\text {th }}$ Ed. Prenticeo Hall International Inc. Engle word Cliffs, New Jersy, $303-339$.

Mostafa,R.A.A.(2008).Effect of bio and organic nitrogen fertilization and elemental Sulphur application on growth, yield and fruit quality of Flame seedless grapevines .Assiut.J.of Agric.Sci., 39(1):79-96.

Peach, K and Tracey, I. M. V. (1968): Modern Methods of Plant Analysis, Vol. I1p.36 - 38. Inter Sci. New York

Ridnour- Lisa, A.; Sim- Julia, E.; Michael, A.H.; David, A.W.; Sean, M.M.; Garry, R.B. and Douglas, R.S. (2000): A spectrophotometric method for the direct detection and quantitation of nitric oxide, nitrite and nitrate in cell culture media. Analytical Biochemistry, 281, 223- 229

Sen, N. P. and Donaldson, B. D. (1978): Improved colorimetric method for determining nitrate and nitrite. Food J. of Assoc. Anal. Chem., 16: 1389 1395.

Shaaban, A.S.A. (2014): Effect of organic fertilization on growth and quality of Superior grapevines. $\mathrm{Ph}$. D., Thesis Fac. of Agric. Cairo Univ. Egypt.
Shekharam, K.M. ; Venkataraman, L.V. \& Salimath, P.V. (1987): Carbohydrate composition and characterization of two unusual sugars from the blue green algae Spirulina platensis. Phytochemistry, 26, 2267.

Snedecor, G. W. and Cochran, G. W. (1967): Statistical Methods (sixth ed.). Iowa State University Press. U.S.A pp 20-25.

Summer. M. E. (1985): Diagnosis and Recommendation. Integrated System (DRIS) as a guide to Orchard fertilization. Hort. Abst. 55 (8). 7502.

Von-Wettstein, D. V. (1957): Chlroophyll- Lethale under submikroshopische formilkechrel der plastiden celi, prp. Trop. Res. Amer. Soc. Hort. Sci. 20 pp. $427-433$.

Wilde, S. A.; Corey, R. B.; Lyer, I. G. and Voigt, G. K. (1985): Soil and Plant Analysis for Tree Culture. Oxford \& IBH publishing Co., New Delhi, pp. 1 218.

Wu, L.C.; Ho, J.A.; Shieh, M.C. and Lu, Y.M. (2005): Antioxidant and antiproliferative activities of Spirulina and Chlorella water extracts. J. Agric. Food Chem., 53 (10): 4207.

\section{كروم استخام الكمبوست التباتى المزود بطحلب الاسبيرولينا بلاتنسيس كبديل جزئى للاسمدة النتروجينية المعدنية فى

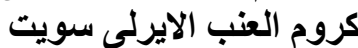

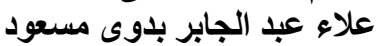 قسم الفاكهة كلية الزراعة- جامعة اسيوطـ مصر بلور}

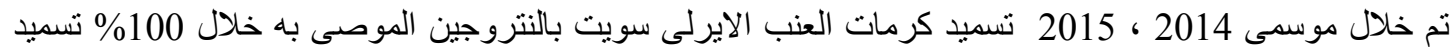

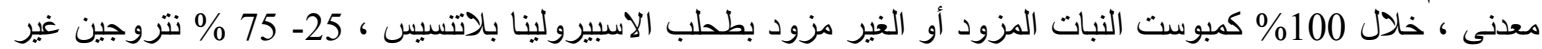

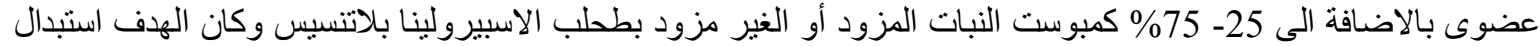

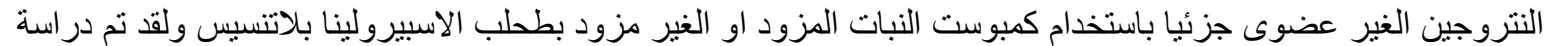

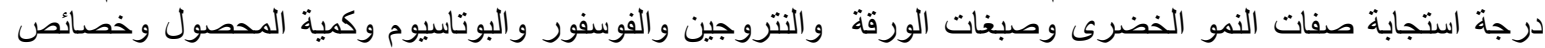

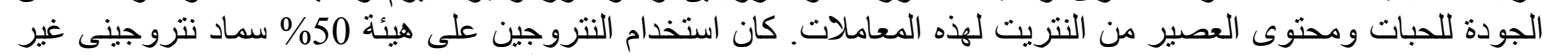

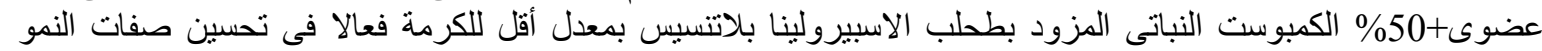

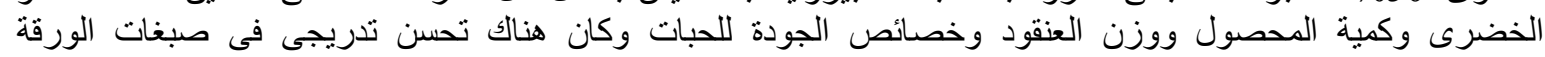

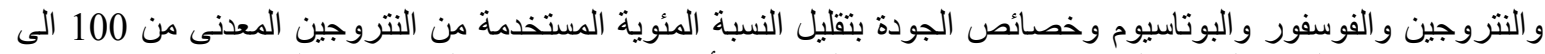

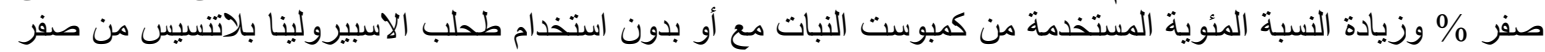

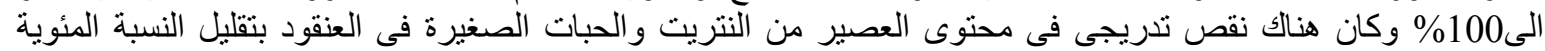

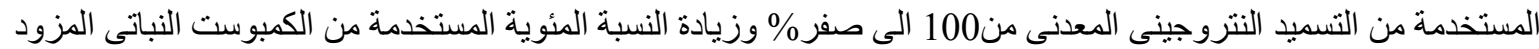

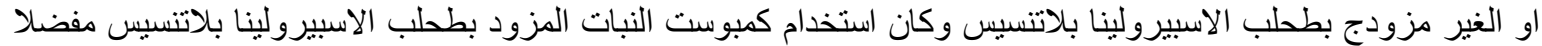

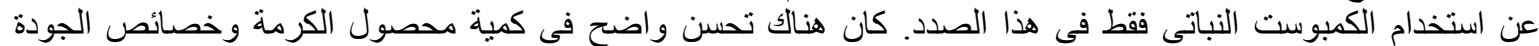

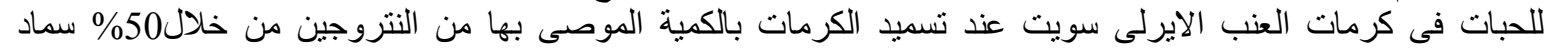
نتروجينى غير عضوى جنبا الى جنب مع استخدام50\% الكمبوست النباتى المزود بطحلب الاسبيرولينا بلاتنسيس بمعدل أقل

$$
\text { الكلمات الادادة : النتروجين الغير عضوى ، الكمبوست النباتى، طلب الاسبيرولينا بلاتتسيس - كرمات العنب الايرلى سويت. }
$$

